蒸葉の電気インピーダンス解析

\author{
独立行政法人 農業・生物系特定産業技術研究機構 野菜茶業研究所* \\ 水上裕造・深山大介・澤井祐典・山口優一 \\ (平成17年 6 月 3 日受理)
}

\title{
Electrical Impedance Analysis of Tea Leaves in the Steaming Process
}

\author{
Yuzo Mizukami, Daisuke Miyama, Yusuke Sawai and Yuichi Yamaguchi \\ National Institute of Vegetable and Tea Science \\ National Agriculture and Bio-oriented Research Organization
}

\section{Summary}

Frequency-dependent electrical impedance spectroscopy has been used to characterize the intracellular and extracellular resistances as well as the capacitance of the cell wall and cell membranes of tea leaves in the steaming process. The intracellular resistance of the steamed leaves decreased by approximately $90 \%$ as compared to that of fresh leaves. Water in the cytoplasm was transformed into mobile water by the steaming treatment. This is the main factor that causes the decrease in the intracellular resistance. However, when the treatment duration exceeded $20 \mathrm{~s}$, there was a negligible influence on the change in the resistance. Therefore, this organized behavior was considered to occur within $20 \mathrm{~s}$. On the other hand, since the indissoluble pectin that constitutes the cell wall became water soluble by the steaming treatment, positive ions accumulated on the cell wall at the beginning of the treatment. Therefore, the capacitance increased temporarily due to the treatment. In addition, when the steaming treatment was prolonged, the capacitance and extracellular resistance decreased due to deterioration and shrinkage of cellular tissues.

Electrochemical impedance analysis can be employed to investigate the organized behaviors that occur in tea leaves in the steaming treatment. Therefore, a numerical method to evaluate the steaming treatment can be established using electrochemical impedance analysis.

Key words : steaming process, electrical impedance, resistance, capacitance

* $\overline{\mathbf{T}} 428-8501$ 静岡県島田市金谷2769 


\section{1 緒言}

緑茶製造において, 蒸熱は茶葉中の酵素活 性を止めると同時に茶葉を柔軟にし，製造を 容易にする最も重要な工程である。茶葉の蒸 熱程度は蒸葉の表裹の色合い, 茎・葉の硬軟 度扔よび香気の発揚具合を中心に官能的に総 合評価されている1)。ただし, 蒸熱程度の判定 は非常に難しく, 原料生葉に適した条件設定 を行うために，熟練者の経験と勘に頼ってい るのが現状である。

蒸熱度判定の数值化に関する研究は, 1980 年代の後半に蒸気量 1 (蒸熱時間2) と蒸葉色の 関係について, また応力測定器を用いた豩離

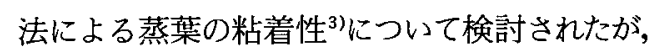
それ以後の報告はほとんどない。製茶技術に おいて蒸熱程度の判定法の確立は茶業界に とって重要な項目の一っであり, そのために はその状態を的確に検出することと，基礎的 な研究の蓄積が必要である。そこで本報では, 電気インピーダンス計測による蒸熱度判定法 の確立を目指し, 蒸葉の電気特性を明らかに することを目的とした。

植物は細胞レベルに执いて, 抵抗と電気容 量の著しく大きな細胞膜・壁とイオン伝導性 を持つ抵抗の小さい細胞液から構成されてい る。低周波領域の交流電界を植物に印加する と, 細胞膜・壁の絶縁性により電流は細胞間 隙を流机る。一方で，印加周波数を増加させ ると細胞膜・壁の絶縁性は低下し, 細胞内部 に電流が流れ始め, 高周波領域では細胞内外 に電流が流れる。この現象は数百Hzから数百 kHzにおいて見受けられ, Maxwell Wagner 効果と呼ばれている4)。したがって幅広い周波 数の掃引により, 細胞内外の電解質濃度や細 胞膜・壁の状態を調べることができる。この ような性質を利用して, 果実の追熟過程にお ける細胞内外の抵抗と細胞膜・壁の静電容量 の変化は, キウイフルーツについて杉山ららお よびBauchotらがが, 桃についてはHarkerら” が明らかにしている。これらの報告をまとめ ると, 追熟にともない細胞組織が軟化するこ とで細胞膜・壁の静電容量は堌加し, 細胞内
の水分が細胞外へ浸出することで細胞外の抵 抗は小さくなることが明らかとなっている。 Harkerら ${ }^{8}$ は岸酸ガス処理によるイチゴ果実 の細胞内外の抵抗変化を調べたところ, 細胞 内抵抗湾化せず, 細胞外抵抗は小さくなる ことを明らかにした。これは炭酸がス処理に より炭酸イオンと水素イオンが細胞外液に溶 解した結果であることから, 細胞外抵抗の変 化を正規化することで，その制御が可能であ ると結論している。竹内ら ${ }^{9}$ は炊飯過程におい て, 糊化の進行にともない細胞外抵抗注減少 し, 細胞内抵抗が増加することをつきとめ, 電気インピーダンス計測で炊飯過程のモニタ リングが可能であることを示した。近年では， 電気インピーダンスは粉ミルクに含まれるバ クテリア数を計測する方法としても注目され

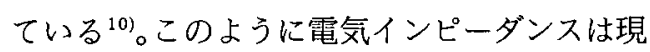
在, あらゆる分野で応用されつつある。

今回, 摘採日の異なる茶葉を材料として用 い, 蒸熱時間を変えて蒸葉の細胞内外の抵抗 と細胞膜・壁の静電容量を電気インピーダン ス計測により求めたところ, 新たなる知見が 得られたので報告する。

\section{2 実験方法}

2005年の一番茶期に野菜茶業研究所試験固 場（金谷）で機械摘みした品種‘やぶきた’を 材料として用いた。摘採日は 5 月 1 日， 6 日， 9 日および14日であり，その原葉特性を表 1 に示した。用いた蒸熱機は送帯式蒸機（SD -500 , 寺田製作所)であり, 蒸熱時間は20秒, 30 秒, 40 秒, 50 秒, 60 秒, 70 秒, 115 秒むょよ゙ 230秒とした。1 回の蒸熱操作で用いた茶葉は

\section{表 1 材料の原葉特性}

\begin{tabular}{ccccc} 
試験区 & 摘採日 & $\begin{array}{c}\text { 百莗重 } \\
(\mathrm{g})\end{array}$ & $\begin{array}{c}\text { 含水率 } \\
(\% \mathrm{~d} . \mathrm{b})\end{array}$ & $\begin{array}{c}\text { 出開き度 } \\
(\%)\end{array}$ \\
\hline \hline $\mathrm{a}$ & 5 月 1 日 & 42.1 & 367 & 55 \\
$\mathrm{~b}$ & 5 月 6 日 & 68.4 & 364 & 71 \\
$\mathrm{c}$ & 5 月 9 日 & 81.7 & 336 & 79 \\
$\mathrm{~d}$ & 5 月 14 日 & 84.6 & 366 & 95 \\
\hline
\end{tabular}




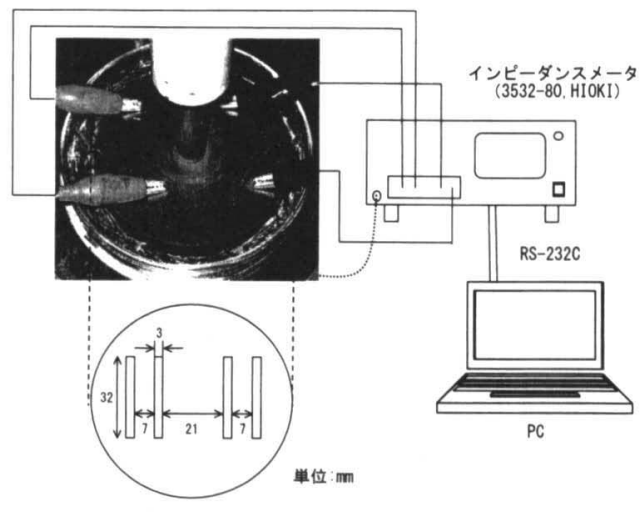

図 1 電気インピーダンス計測システム

約 $500 \mathrm{~g}$ であり, 茶葉温度が $20^{\circ} \mathrm{C}$ から $26^{\circ} \mathrm{C}$ に低 下するまで室内で冷却後, 蒸葉 $10 \mathrm{~g}$ の電気イン ピーダンスを計測した。なお計測は 3 回繰返 した。

\section{1 電気インピーダンス計測方法}

電気インピーダンスは交流 4 端子法により 計測した。図 1 に示したように，ガラス皿に 茶葉をのせ, その上から幅 $3 \mathrm{~mm}$, 厚さ $1 \mathrm{~mm}$, 長さ $32 \mathrm{~mm}$ のステンレス製の電極を取付けた円 形状のゴム板を押し当て,インピーダンスメー 夕 (3532-80, HIOKI) で50mVの電圧を茶葉 に印加し, $500 \mathrm{~Hz}$ から $500 \mathrm{kHz}$ の周波数におい て25点の電気インピーダンスZと位相角 $\theta$ を計 測した。なお, ガラス皿にアルミ板を接触さ せ, インピーダンスメータのガード端子と接 続することでノイズの影響を防いだ。電極部 および測定ケーブルの残留インピーダンスは 計測值に影響を及ぼすため, ショートとオー プンの二つの状態において電気インピーダン スを計測し, 実測值から差し引くことで計測 值を補正した。

\section{2 等価回路とその解析方法}

細胞組織に起因する構造分散の定量的評価 には, 電気インピーダンスの周波数特性に対 応した電気的に等価な回路を仮定し，その素 子の定数を求める方法が用いられている(5) 11) 測定した電気インピーダンスの周波数応答と 細胞組織の周波数特性との関係を調べるため,
図 2 aに示したHayden ${ }^{11}$ モデルを簡略化した モデルを採用した（図 2 b)。

計測された電気インピーダンス $Z$ と位相角 $\theta$ から抵抗 $\mathrm{R}$ は $\mathrm{R}=|Z| \cos \theta$ の式で, またリア クタンスXは $X=|Z| \sin \theta$ の式で算出できる。 このモデルのように容量成分を含む回路では, 周波数軌跡は円弧の一部となる。

通常, 細胞膜・壁の抵抗 $\mathrm{R}_{\mathrm{m}}$ は非常に高いの で,簡略化されたモデルでは図 $2 b$ bうう $R_{m}$ を省略する。細胞内膜器官の影響を考慮し, 膜要素を細胞内抵抗に含んだdouble shell mode ${ }^{11}$ が提唱されているが, 数百 $\mathrm{kHz}$ 以下の 計測ではこれらの分散は起こらず，より要素 の少ないHaydenモデルが十分成立するとされ ている。図 $2 \mathrm{c} に は$ 蒸葉の電気インピーダンス

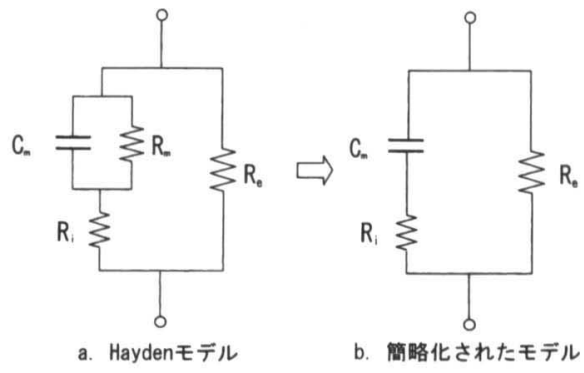

几

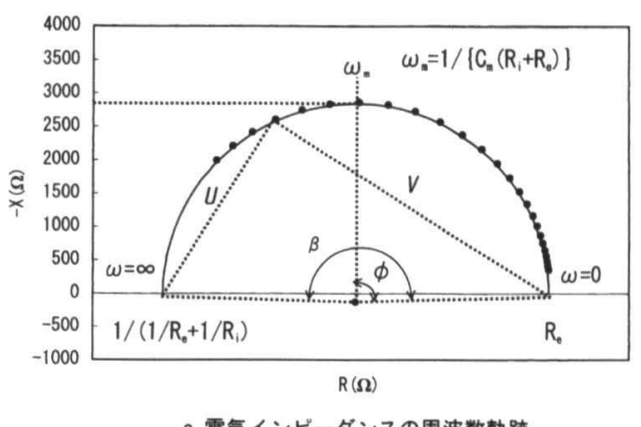

図 2 Haydenモデルと電気インピーダンス の周波数軌跡

$\mathrm{R}_{\mathrm{e}}$ : 細胞外抵抗

$\mathrm{R}_{1}$ : 細胞内抵抗

$\mathrm{C}_{\mathrm{m}}$ : 細胞膜 - 壁容量

$\mathrm{R}_{\mathrm{m}}$ : 細胞膜 $・$ 壁抵抗

$\omega$ : 角周波数

$\phi:$ 円弧の中心角

$\beta: 2 \phi / \pi$ 
の周波数軌跡の一例を示した。図中に示した $\mathrm{R}_{\mathrm{e}}$ は細胞外抵抗, $\mathrm{R}_{1}$ は細胞内抵抗であり, $\mathrm{C}_{\mathrm{m}}$ は細胞壁・膜の容量成分である。角周波数 $\omega_{\mathrm{m}}$ が図中に示されているが,この点は $\mathrm{X}=|Z| \sin \theta$ が最大の時の角周波数であり, $\mathrm{C}_{\mathrm{m}}$ と $\mathrm{R}_{\mathrm{f}}$ および $\mathrm{R}_{\mathrm{e}}$ にるる簡単な式で表せる。

電気インピーダンスの周波数軌跡が円弧と なることを確認後, 円の方程式 $(\mathrm{x}-\mathrm{a})^{2}+(\mathrm{y}$ $-\mathrm{b})^{2}=\mathrm{r}^{2}$ を前提に, 求められた 25 点の $\mathrm{R}$ Xを コンピューターに入力し, 重み付き回帰分析

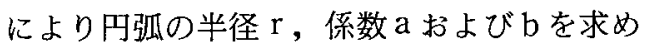
た。さらに求められた円の方程式から図 $2 \mathrm{ck}$ 示した $\mathrm{R}_{1}, \mathrm{R}_{\mathrm{e}}$ および円弧の中心角 $\phi$ を計算し た。

周波数軌跡が円弧の一部となることの確認 と細胞膜・壁の静電容量 $\mathrm{C}_{\mathrm{m}}$ の計算は杉山ら の方法を参考にした。すなわち図 2 cにおいて, 円弧の中心角 $\phi$ を慣例により $\phi=\beta \pi / 2$ とおく。

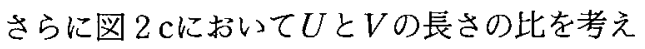
ると, 周波数 $f$ を変数として, $\log |V / U|=\alpha \log$ $f+\alpha \log \left(2 \pi / \omega_{m}\right)$ の式が導かれ, $\log f$ の直線 の傾きより $\alpha$ が求まる。この時， $\alpha=\beta$ となれ ば周波数軌跡は円弧となり，これはよく知ら れたCole-Cole分散系のインピーダンス表現式 となる。式の傾き $\alpha$ と切片 $\alpha \log \left(2 \pi / \omega_{m}\right)$ から $\omega_{m}$ が算出され， $\mathrm{C}_{\mathrm{m}}$ を求めることができる。

以上の解析を行うにあたり, Microsoft Excelのマクロを用いた。

\section{3 解析精度の検証方法}

解析精度を検証するため, 許容差 $1 \%$ 以下 の抵抗器と許容差 $5 \%$ 以下のコンデンサを用 いて, $\mathrm{R}_{\mathrm{e}}$ が1.2k $\Omega$ から $1.8 \mathrm{M} \Omega, \mathrm{R}_{\mathrm{i}}$ が0. $39 \mathrm{k} \Omega$ か ら $33 \mathrm{k} \Omega, \mathrm{C}_{\mathrm{m}}$ が1. $5 \mathrm{nF}$ おび7.0nFとなるよう 図 2 bの等価回路を 10 種類作成し, 電気イン ピーダンスの周波数軌跡を解析した。なお, 計測は $20^{\circ} \mathrm{C}$ から $26^{\circ} \mathrm{C}$ 下, $31 \% \mathrm{RH} ら 65 \% \mathrm{RH}$ 下の環境下で行い, いずれも 3 回繰返した。

\section{3 実 験 結 果}

\section{1 解析精度}

$\mathrm{R}_{\mathrm{e}}, \mathrm{R}_{\mathrm{i}}$ および $\mathrm{C}_{\mathrm{m}}$ の計測詰差は, $20^{\circ} \mathrm{Cから}$ $26^{\circ} \mathrm{C}$ 下, $31 \% \mathrm{RH}$ から $65 \% \mathrm{RH}$ の環境下におい
て抵抗器およびコンデンサの許容差内であつ た。繰返し計測による誤差はいずれも $0.01 \%$ 以内の変動係数であった。

一般に $1000 \mathrm{kHz}$ 以上の交流電界において， 空気の状態量の中でも温湿度は計測された抵 抗や静電容量に影響を及ぼすが4)，500k Hz以 下の周波数では今回計測した環境下において， 温湿度の影響を受けなかった。したがって， 茶葉の電気的特性を計測する際には， $20^{\circ} \mathrm{Cか}$ ら $26^{\circ} \mathrm{C}$ 下，31\%RHから65\%RHの環境下で計 测することにした。図 $2 \mathrm{~b}$ 示した等価回路の 抵抗值および静電容量値と解析により求めら れた值はほぼ同程度であったことから，茶葉 の電気インピーダンスの周波数軌跡が円弧の 一部となれば,茶葉の細胞内外抵抗と細胞膜・ 壁の静電容量を精度よく計測できることがわ かった。

\section{2 生葉と蒸葉の周波数特性}

今回計測した原料生葉と蒸葉の $\alpha$ おび $\beta$ は 0.54 から0.950範囲でほほ同程度であり, log $|U / V|$ と $\log f$ は相関係数 0.998 以上の線形関 係であった。したがって，今回実験に用いた 原料生葉と蒸葉の電気インピーダンスの周波 数軌跡は円弧の一部となることがわかった。

\section{3 紏胞内外の抵抗}

図 3 に蒸熱時間と細胞内外抵抗の関係を示 した。図中の a 5 月 1 日, b は 6 日, c は 9 日，dは14日に摘採した生葉を材料として いる。

原料生葉の細胞内抵抗は 5 月 1 日で $8 \mathrm{k} \Omega$, 6 日で $12 \mathrm{k} \Omega ， 9$ 日で $14 \mathrm{k} \Omega$ ，また 14 日で $16 \mathrm{k} \Omega$ と摘採日が進むにつれ增加した。ただし，蒸 熱後,いずれも約 $90 \%$ 程度減少した。さらに 細胞内抵抗は，20秒以上の蒸熱において摘採 日と蒸熱時間の影響を受けず，ほぼ一定の值 であった。

原料生葉の細胞外抵抗は 5 月 1 日で 80 $\mathrm{k} \Omega ， 6$ 日で $99 \mathrm{k} \Omega ， 14$ 日で $249 \mathrm{k} \Omega$ ，また14日で $300 \mathrm{k} \Omega$ と, 細胞内抵抗と同じく摘採日が進むに つれ増加した。 5 月 1 日に摘採した生葉を材 料とした場合（図 $3 a$ ), 本条件において, 蒸 

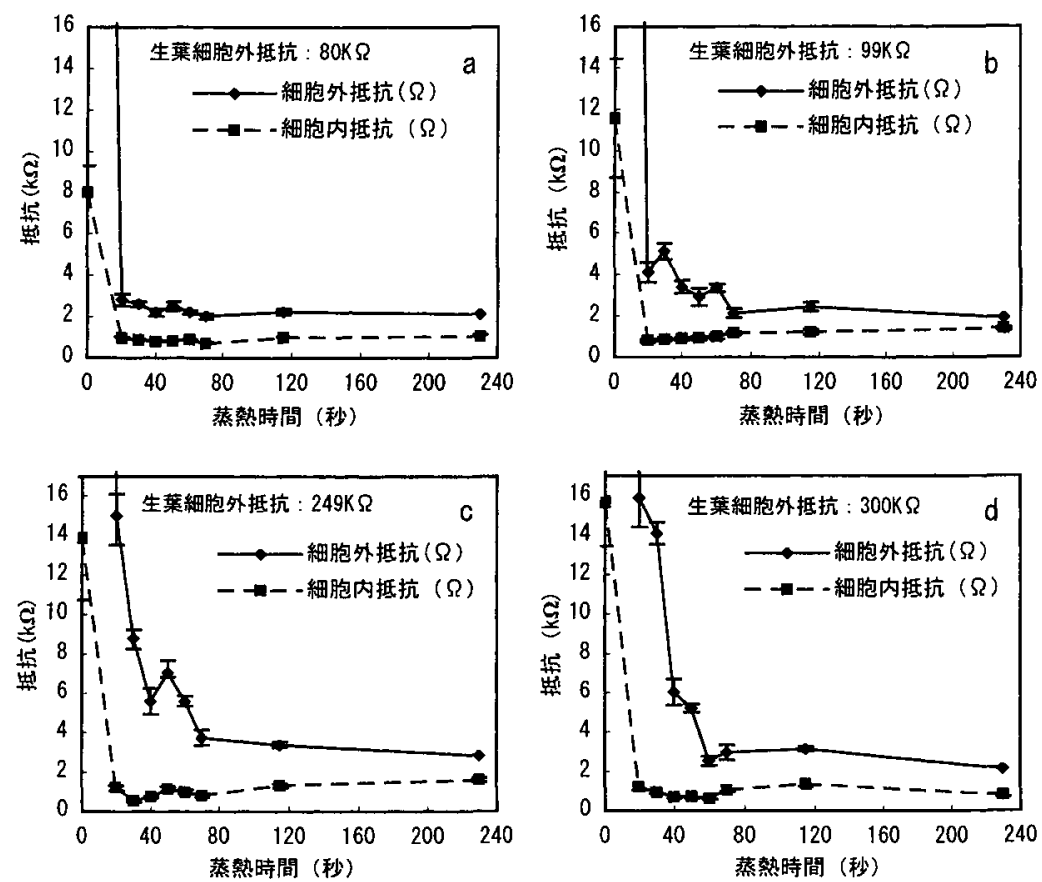

図 3 蒸熱時間が細胞内外の抵抗に及ぼす影響

$(\mathrm{a} ： 5$ 月 1 日, b： 5 月 6 日, $\mathrm{c} ： 5$ 月 9 日, $\mathrm{d} ： 5$ 月 14 日)
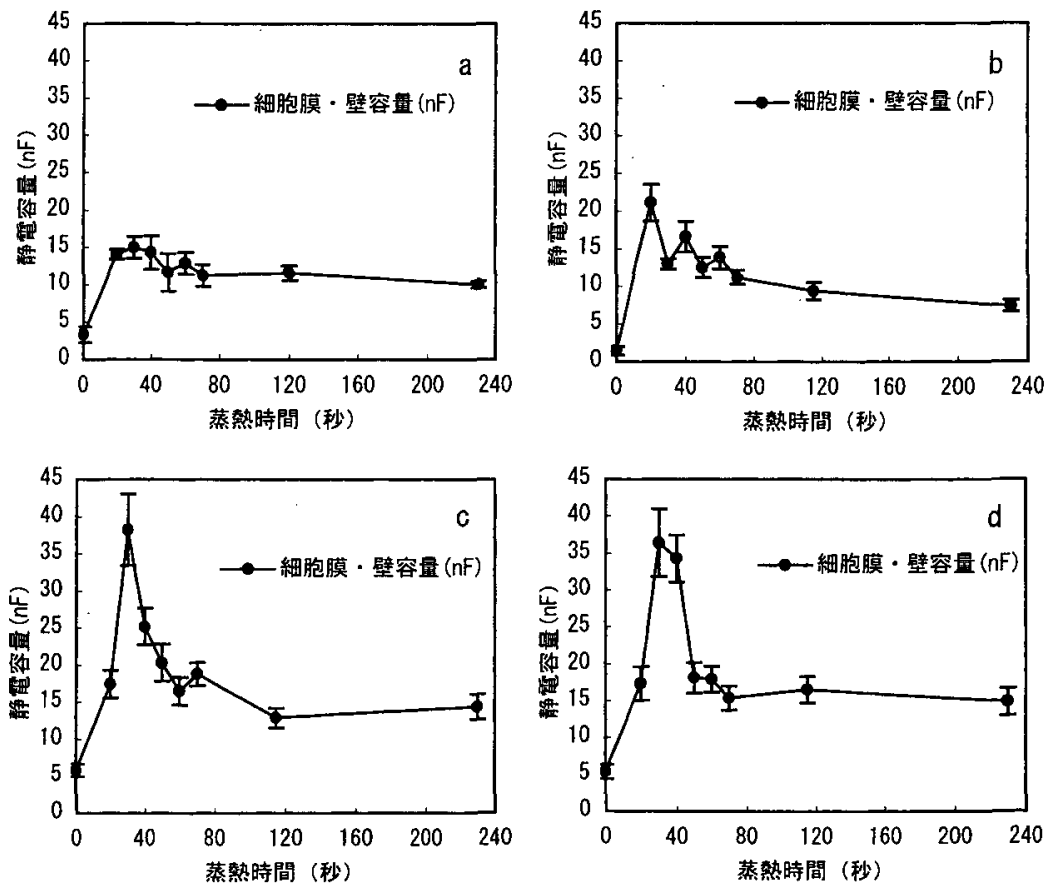

図 4 蒸熱時間が細胞膜・壁の静電容量に及ぼす影響

$(\mathrm{a} ： 5$ 月 1 日, $\mathrm{b}: 5$ 月 6 日, $\mathrm{c} ： 5$ 月 9 日, $\mathrm{d} ： 5$ 月14日) 
葉の細胞外抵抗は蒸熱時間の影響を受けず，

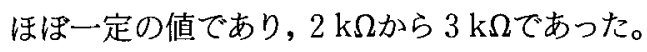
摘採日が進むにつれ，20秒の蒸熱時間におけ る細胞外抵抗は高く,また蒸熱時間が長くな るにつれその值は澸少した。ただし，いずれ においても70秒から230秒の蒸熱時間では, 細 胞外抵抗はほほ同程度の値であった。

\section{4 細胞膜・壁の静電容量}

図 4 に蒸熱時間と静電容量の関係を示した。 図中の $\mathrm{a}$ は 5 月 1 日, b は 6 日, c は 9 日， $\mathrm{d}$ は14日に摘採した生葉を材料としている。

5 月 1 日に摘採した生葉の静電容量は 3 $\mathrm{nF}, 6$ 日は $1 \mathrm{nF}, 9$ 日と14日は $5 \mathrm{nFであった}$ が，いずれも蒸熱により増加した。5月 1 日 に摘採した生葉を材料とした場合（図 4 a), 20 秒から 230 秒の蒸熱時間において,その值は ほほ同程度であった。蒸熱時間が長くなるに つれ，若干滅少しているように見えるが，有 意な差は認められなかった $(\mathrm{p}>0.05) 。 5$ 月 6 日に摘採した生葉を材料とした場合では(図 4 b), 20秒の蒸熱時間で20nF程度であったが, 蒸熱時間が長くなるにつれ減少し,230秒の蒸

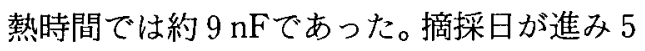
月 9 (図 $4 \mathrm{c}$ ) および14日（図 $4 \mathrm{~d}$ ) の生葉を 材料とした場合では, 30秒の蒸熱で静電容量 のピークを迎え,それぞれ約 $38 \mathrm{nF}$ おび $36 \mathrm{nF}$ であった.いずれも30秒より蒸熱時間を長く すると静電容量は減少し，70秒を超えてから は一定した。

\section{4 考察}

本結果を見ると, 茶葉の熟度に関係なく, 20 秒より長い蒸熱は細胞内抵抗に影響を及ほ さなかった。このことは，20秒より長い蒸熱 は細胞内の電解質濃度に影響を及涩さなかつ たと解积できる。ただし，生葉の細胞内抵抗 $8 \mathrm{k} \Omega$ から $16 \mathrm{k} \Omega \mathrm{k}$ 比心, 蒸葉の細胞内抵抗はそ の約10\%程度まで減少した。向井ら ${ }^{12)}$ は蒸葉と 生葉の水のプロトン緩和時間から水の存在状 態を調べ, 生葉は動きやすい水と細胞質内に 存在する動きにくい水が存在するが, 蒸葉は 細胞質内の水と細胞間陌に存在する水の分離
が消失して, 動きやすい水が一様な状態で存 在すると報告している。蒸熱により細胞質内 の水が動きやすい水となることで, 電解質の 流動性が高まり，結果として細胞内抵抗が減 少したものと理解できる。本結果より，この 現象は茶葉の熟度に関係なく, 20秒以内の蒸 熱で起こることがわかる。

一方, 細胞外抵抗が蒸熱により減少した原 因は以下のようなことが考えられる。植物の 細胞壁は外側から中間ラメラ, 第一細胞壁, 第二細胞壁に分かれ，中間ラメラは主として ペクチンより構成されリグニンも含む。第一 練胞壁はセルロース，人ミセルロース，ペク チン,リグニンよりなり，最も内側にある第 二細胞壁は主としてセルロースから構成され ている ${ }^{13)}$ 。細胞壁でペクチンはカルシウム, マ グネシウムなどの陽イオンにより不溶性を増 しそのために植物は形を維持している ${ }^{14)}$ 。一 般に加熱処理によって不溶性ペクチンがトラ ンスエリミネーションによって分解されるこ とで細胞間の結合力が失われることが知られ ており ${ }^{14)}$,これが蒸熱による軟化の原因の一つ であると考えられる。また蒸熱時間を長くし ても全ペクチン含量は変わらないが, 水溶性 ペクチンが増加する(5)ことが知られている。さ らに加熱によってペクチンから陽イオンが放 出されることで, 水溶性ペクチンとなること

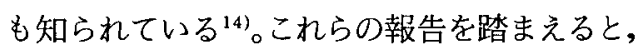
蒸熱時間を長くすると細胞外抵抗が減少する 要因は, 細胞を覆っている不溶性ペクチンが 蒸熱により水溶性ペクチンとなることで陽イ オンが溶出し, 細胞間隙に存在する水の電解 質濃度が高まったためであると考えられる。 ただし，熟度が進んだ茶葉において70秒以上 の蒸熱は細胞外抵抗に影響を及ほさなかった。 高柳ら ${ }^{15)}$ は蒸熱時間が30秒, 60秒, 150秒と長 くなるにつれ，水溶性ペクチンの増加を認め ているが，これは細胞外抵抗に影響を及ほさ ない程度で不溶性ペクチンが水溶性となった ことが考えられる。細胞外抵抗が減少した理 由として, ペクチンの水溶性化による細胞間 吵の電解質濃度の増加以外にも以下のことが 考えられる。Harkerら ${ }^{16}$ は, 細胞膜・壁の少 
化により細胞内から細胞外へイオン漏出と水 の漏出が同時に起こり, 細胞外抵抗が減少す ることを報告している。蒸熱によりこれらの 挙動が起こったことも十分に考えられる。こ れらを踏まえると，5月1日に摘採した生葉 を蒸熱した場合, 細胞外抵抗は20秒より蒸熱 時間を長くしてもその值は変わらなかったこ とから,これらの挙動は20秒以内に終了して いるものと考えられる。ただし，5月9日お よび 5 月14日に摘採したような熟度が進んだ 茶葉を蒸熱した場合, これらの挙動は70秒以 内に行われたと理解できる。

静電容量は電荷を蓄える容量であり， $\mathrm{C}=$ $\varepsilon \times \mathrm{S} / \mathrm{d} て ゙$ 表すことができる。ここでとは比誘電 率であり， $\mathrm{S}$ は表面積， $\mathrm{d}$ は厚さである。本 結果のように, 蒸熱処理により静電容量が一 時的に増加したことは, 細胞膜・壁の $\varepsilon$ との 増加か，あるいはdの減少か，もしくはそれ らが同時に起こった結果であると考えられる。 桑原ら ${ }^{17)}$ は蒸熱により原形質分離が起こること を報告しており，それにより，極わずかであ るが細胞膜の d が小さくなったために静電容 量が増加したとも考えられる。しかし, 今回 計測した $500 \mathrm{~Hz}$ から $500 \mathrm{kHz}$ の周波数において は, 細胞膜と壁の総静電容量を計測している ため, 静電容量の増加は原形質分離の挙動を 表していないと理解するのが自然である。前 述したように, 細胞壁のペクチンが水溶性ペ クチンとなることで, 細胞壁内に陽イオンが

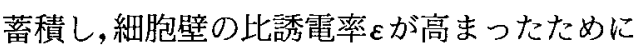
静電容量が増加したと考えられる。ただし， 蒸熱時間が長くなるにつれ静電容量は減少し

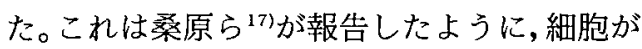
収縮することで表面積 Sが減少したことと， 蒸熱により細胞壁・膜が劣化することで細胞 膜・壁に存在するイオンが漏出し ${ }^{16)}$, 比誘電率 とも小さくなったことが原因であると考えられ る。本結果をみると，5月1日に摘採したよ うな熟度が若い茶葉では，これらの挙動は20 秒以内の蒸熱で終了するが，5月 9 日および 5 月14日のような熟度が進んだ茶葉では70秒 以内の蒸熱で終了するものと考えられる。 以上の考察をまとめると, 蒸熱初期におい
て, 細胞内の水が動きやすい水となることで 細胞内抵抗は減少した。一方で, 蒸熱により 細胞壁を構成する不溶性ペクチンが水溶性と なることで，陽イオンが細胞壁に蓄積され， 一時的に静電容量は堌加し，それと同時に細 胞外へ陽イオンの溶出も起り, 細胞外抵抗は 減少した。また，蒸熱時間を長くすると，細 胞膜・壁の劣化と収縮が起こるため, 細胞外 抵抗と静電容量は減少した。ただし，これら の挙動の進行具合には原料茶葉の熟度による 違いが見られた。

電気インピーダンス計測により蒸葉の解析 を行い，蒸熱工程における茶葉の細胞内外抵 抗と静電容量を求め, 新たなる知見が得られ た。これらの指標を正規化することにより， 電気インピーダンスは新たな蒸熱程度の計測 方法として利用できる可能性がある。

\section{5 摘 要}

蒸葉の電気インピーダンスを解析し，知見 が得られた。蒸葉の細胞内抵抗は生葉に比べ ると約 $90 \%$ 程度減少した。これは細胞内の水 が動きやすい水となったことが主要因であり, これらの挙動は蒸熱初期に起こると考えられ た。一方で, 蒸熱により細胞壁を構成する不 溶性ペクチンが水溶性となることで, 陽イオ ンが細胞壁に蓄積され，一時的に静電容量は 増加し，それと同時に細胞外へ陽イオンの溶 出も起り, 細胞外抵抗は減少したと考えられ た。また, 蒸熱時間を長くすると紐胞組織の 劣化や収縮により静電容量と細胞外抵抗は減 少することが理解できた。

電気インピーダンスは, 細胞内外の抵抗や 細胞膜・壁の状態を調べる上で有効な方法で あり，新たな蒸熱程度の判定法として利用可 能である。

\section{6 謝 辞}

本実験を遂行するにあたりご協力頂きま した入江隼之介さん，尾上雄也さんに感謝申 し上げます。 


\section{7 引用文献}

1）大森薫 - 中村晋一朗・渡辺敏郎 (1986)： 蒸熱条件の違いによる茶葉色の変化（第 1 報)。茶研報，63，24-29。

2 ）大森薫・中村晋一朗・渡辺敏郎 (1986): 蒸熱条件の違いによる茶葉色の変化（第 2 報)。茶研報, 63，30-34。

3 ）上辻久利 (1988)：蒸し葉の物理測定によ る判定法.京都府立茶業研究所研究報告, $20,16-21$.

4) 豊田淨彦 (2003)：電気的特性の利用. 河 野澄夫編, 食品の非破壞計測ハンドブッ ク,サイエンスフォーラム, 東京, pp.84-91.

5 ) 杉山純一・林徹・堀内久弥 (1987)：キウ イフルーツのインピーダンス特性.食工誌, 34, 725-730.

6) Bauchot A. D., Harker F. R. and Arnold W. M. (2000) : The use of electrical impedance spectroscopy to assess the physiological condition of kiwifruit. Post. Bio. Tech., 18, 9-18.

7) Harker F. R. and Dunlop J. (1994): Electrical impedance studies of nectarines during coolstorage and fruit ripening. Post. Bio. Tech., 4, 125-134.

8) Harker F. R., Elgar H. J., Watkins C. B., Jackson P. J. and Hallett I. C. (2000): Physical and mechanical changes in strawberry fruit after high carbon dioxide treatments. Post. Bio. Tech., 19, 139-146.

9 ) 竹内龍三・豊田淨彦 (2000)：電気イン ピーダンスによる炊飯過程のキャラクタ
ライゼーション. 㞳阜女子大学紀要, 29 , 155-159.

10) Walker K., Ripandelli N. and Steve Flint S. (2005) : Rapid enumeration of Bifidobacterium Lactis in milk powders using impedance. International Dairy Journal, 15, 183-188.

11) Zhang M. I. N., Stout D. G. and Willison J. H. M. (1990): Electrical impedance analysis in plant tissues: symplasmic resistance and membrane capacitance in the Hayden model. J. Exp. Bot., 41 (224), 371-380.

12）向井俊博 - 堀江秀樹 - 深津修一 - 䄂田勝 彦·後藤哲久 (1992)：製茶工程中の水の 存在状態のNMRによる解析. 茶研報, 75, 23-27.

13) E. E. Conn., P.K. Stumpf., G.Bruening and R.H.Doi. (1988)，8.1.2植物細胞壁， 東京化学同人, コーンスタンプ生化学(第 5 版), 田宮信夫・八木達彦訳, 東京, pp. 257-258.

14）渕上倫子 (1983)：野菜の軟化に及ほす加 熱時のpHの影響. 日栄食誌, 36 (4), 219-224.

15）高柳博次 - 阿南豊正 - 池ケ谷賢次郎 （1987）：蒸し度の差異による製茶の理化 学性の変化, 茶研報, 65, 81-85.

16) Harker F. R and J. H. Maindonald (1994) : Ripening of Nectarine Fruit. Plant Physiol, 106, 165-171.

17）桑原穆夫・中山仰 (1949)：茶葉組織の製 茶操作による変化(第 1 報)。茶研報, 2 $29-34$. 